\title{
LINEAR AND SPATIAL VARIABILITY OF FODDER PRODUCTIVE COMPONENTS CORRELATED WITH MICRONUTRIENT LEVELS OF THE SOIL
}

\author{
Pamela Kerlyane Tomaz ${ }^{1}$; Rafael Montanari, ${ }^{2,}$; Marcelo Andreotti²; Alan Rodrigo Panosso ${ }^{3}$ \\ ${ }^{1}$ Post Graduate Student of the Animal Science course, Engineering College, UNESP, Ilha Solteira, São Paulo (Brazil). ${ }^{2}$ Full \\ Professor of Phytosanitary Department, Agricultural Engineering and Soils- Engineering College, UNESP, Ilha Solteira, \\ São Paulo (Brazil). ${ }^{3}$ Assistant Professor of the Mathematics Department - Engineering College, UNESP, Ilha Solteira, São \\ Paulo (Brazil). \\ ${ }^{*}$ Corresponding author: montanari@agr.feis.unesp.br
}

ABSTRACT: The knowledge over the soil chemical analysis results is one of the initial steps for the determination of the fertilizer recommendation, given that, for micronutrients in pastures, the works are scarce. The aim of this study was to evaluate the linear and spatial variability of the soil micronutrient levels in an experimental area under pasture, with Urochloa spp. hybrids, in a total of 17.6 ha. The predominant soil in the area was the Dystrophic Red-Yellow Argisol. In previous years, maize and sugarcane were cultivated in the researched area. A regular sampling mesh of $30 \times 30 \mathrm{~m}$ was used, with 195 points of soil collect at 0.0-0,1 $\mathrm{m}$ and 0.1-0.2 $\mathrm{m}$ depths and a complete chemical analysis (390 samples) was conducted. The evaluated plant attributes were the height (Hei) and the dry mass of fodder production (DMF). The soil attributes were B, Zn, Cu, Fe and Mn. Mathematical models depending on B, Fe, and Mn for the 0.0-0.1 m depth could explain the DMF productivity. The higher ranges of spatial dependence were observed for the attributes of DMF and $\mathrm{Fe}$ in the depths of 0.0-0.1 $\mathrm{m}$ and 0.1-0.2 $\mathrm{m}$. The average use of the results can provide errors when taking decisions about the micronutrients fertilization, by its high spatial variability.

Key words: Spatial dependence, soil chemistry, geostatistics.

\section{VARIABILIDADE LINEAR E ESPACIAL DE COMPONENTES PRODUTIVOS DA FORRAGEM CORRELACIONADOS COM TEORES DE MICRONUTRIENTES DO SOLO}

RESUMO: O conhecimento sobre os resultados da análise química do solo é um dos passos iniciais para determinar a recomendação de adubação, sendo que para micronutrientes em pastagens os trabalhos são escassos. O objetivo com este estudo foi avaliar a variabilidade linear e espacial dos teores de micronutrientes do solo em uma área experimental sob pastagem, com híbridos de Urochloa spp., num total de 17,6 ha. O solo predominantemente na área foi o Argissolo Vermelho-Amarelo distrófico. Em anos anteriores na área pesquisada foi cultivado milho e cana-de-açúcar. Foi utilizada uma malha de amostragem regular de $30 \times 30$ m, com 195 pontos de coleta de solo em profundidades de 0-0,10m e 0,10-0,20m e realizada uma análise química completa (390 amostras). Os atributos de planta avaliados foram a altura (Alt) e a produção massa seca da forragem (MSF). Os de solo foram os teores B, Zn, Cu, Fe, Mn e. A produtividade de (MSF) pôde ser explicada, por modelos matemáticos em função do B, Fe e Mn para a profundidade de 0.0-0.1 m. Os maiores alcances da dependência espacial foram observados para os atributos de MSF e Fe nas profundidades de 0.0$0.1 \mathrm{~m}$ e 0.1-0.2 m. A utilização da média dos resultados pode proporcionar erros na tomada de decisões quanto a adubação com micronutrientes, pela alta variabilidade espacial.

Palavras-chave: Dependência espacial, química do solo, geoestatística.

Received: Aug. 16, 2016 - Accepted: Dec. 08, 2016 


\section{INTRODUCTION}

Brazil has 220 million hectares of pastures, being the gender Urochloa (Syn. Brachiaria) the predominant grass, with $55 \%$ of $U$. decumbens, which presents a good adaptation to the soil and to the tropical climate. The neglect of the pasture areas is historic and arises of an extractivist mentality that endures until today in the livestock farming (Dias-Filho \&Bernadino, 2014).

The natural ecosystems alteration occurs as far as they are being replaced by activities focused on industrial purposes or food production, resulting in degradation originated from the inappropriate use and management of the soil. However, with time, not even these rustic fodder have been managed a good development in these soils, because the consumption of the green mass by the animal, the lack of replacement of nutrients, soil acidification, loss of organic matter and soil compaction decrease the pastures productive efficiency (Moreira et al., 2005).

In Brazil, soil degradation and low pasture productivity have deserved attention from the Agronomic class and the rural producers, by definition, is designated as pasture degradation to the evolutionary process of vigor loss, productivity and capacity of its natural recovery, making it unable to sustain the production and quality levels required by the animals, just as well to overcome the harmful effects of pests, diseases, and weeds, which in an advanced stage can result in considerable natural resources degradation (Macedo, 1995).
Geostatistics is a tool used for the study of the spatial variability of soil and plant attributes, having the semivariogram as an element that attests its applicability. Its use requires the sample collection previously planned, with the exact spatial location of each sample point. Geostatistical studies have demonstrated the influence of the soil attributes on the plant productivity pattern and spatial distribution.

Thus, it is known that the plant works in order to respond, especially when its productivity is spatially analyzed, in a positive and/or negative form, according to the behavior of the soil attributes variability. On the other hand, being the semivariogram a basic supporting tool to the geostatistical mapping by kriging techniques, this allows quantitatively represent the spatial behavior of a representative regionalized variable of any attribute (Silva et al., 2000).

So, this study aimed to define the linear and spatial correlations of the soil micronutrient levels, with the growth and dry mass production of brachiaria grass installed in the experimental area of the Zootechnical Institute (ZI) in Nova Odessa-SP.

\section{MATERIAL AND METHODS}

The experiment was conducted in an area located at the Zootechnical Institute (ZI), located in Nova Odessa City - SP (Brazil). The designated area for the experiment has 17.6 ha. It is located in a subtropical climate region, with dry winter and hot and humid summer, with Köppen climatic classification as Aw, with an average temperature of 21.7 o $C$ and average rainfall precipitation of 1,368 mm per year (CEPAGRI, 2013). 
The predominant soil of the area was classified in the Brazilian Soil Classification System (EMBRAPA, 2013) as abrupt to moderate Dystrophic Red-Yellow Argisol, with a sandy/medium texture.

A sampling grid was defined which contemplated the same ratio of samples per area to all pickets, considering a minimum of 10 points per hectare. The sampling mesh was traced over the planimetric survey data carried out in April 2012 on a regular form and with a spacing of $30 \times 30 \mathrm{~m}$. The spatial reference system used in the planimetric survey and in the georeferenced points was the Sirgas [(2000) Geocentric Reference System for the Americas].

The result generated 195 sample points. The digital file of the sampling grid was georeferenced in 7 points known by the planialtimetric survey with the Magellan geodesic GPS, Pro Mark 500 model, equipped with the RTK Ntrip device.

For the sample collection for evaluation of the fodder green mass, were used a template with dimensions of $2 \times 2 \mathrm{~m}$, and the existing material inside the square was mown at approximately $0.25 \mathrm{~m}$ of the soil. Then, a sample of this material was removed and was stored in paper bags, weighed and placed in a forced air circulation oven, by determining, thus, the fodder dry mass. The relative fodder dry mass (DMF) was obtained through the relation between the green and dry mass of the fodder subsample. For the evaluation of the height (Hei) of the lawn was used, graduated ruler.

The soil sampling was carried out in April 2013, taking as reference the marked points in the field, where the samples were collected distancing itself $0.15 \mathrm{~m}$ of the stake in the west direction of the land in two depths 1
(0.0-0.1 m) and 2 (between 0.1-0.2 m) totaling 390 samples of soil. To this sampling was used a Dutch auger, with a bucket with a length of $0.1 \mathrm{~m}$, and diameter of $0.038 \mathrm{~m}$.

The collected soil samples were conditioned in plastic bags, identified and sent to the laboratory for soil chemical composition analysis about the $\mathrm{Cu}, \mathrm{Fe}, \mathrm{Mn}$ and $\mathrm{Zn}$ (extractor DTPA - TEA pH 7.3) and B (hot water) levels, according to the methodology of Raij et al. (2001).

For each studied attribute, was made the classical descriptive analysis, with the aid of the statistical software SAS (Schlotzhaver \& Littell, 1997), in which were calculated the average, median, minimum and maximum values, standard deviation, the coefficient of variation, kurtosis, skewness, and frequency distribution. Later, it was held the identification of the outliers, making the replacement of its values by the average value of the surrounding contained in the mesh. To test the normality or log-normality hypothesis, the Shapiro \& Wilk statistics at 5\% was used.

Likewise, the correlation matrix was set up, aiming to perform the simple linear correlations for the combinations, two by two, among all studied attributes, as well as present the regressions analysis for the pairs of best interest. Thus, were selected those with higher linear correlation and that, therefore, could present cross-semivariogram and consequent co-kriging. Separately for each attribute, was analyzed its spatial dependence, by calculating the simple semivariogram.

However, for those that presented spatial interdependence, it was also calculated its cross-semivariograms, based on the presumptions of the stationarity intrinsic 
hypothesis, by the use of the Gamma Design Software package (GS+, 2004). The adjustment of the simple and crossed semivariogram, in function of their models, were priority made by the beginning selection:

a) the smaller sum of squares of deviations (SSD);

b) higher coefficient of determination $\left(r^{2}\right)$;

C) higher evaluator of spatial dependence (SD).

The final decision of the model, which represented the adjustment, was carried out by the crossed validation, as well as to define the neighborhood size that provided the best mesh of kriging and/or co-kriging, made through kriging in blocks. For each attribute, were related the nugget effect $\left(C_{0}\right)$, the range $\left(A_{0}\right)$ and the level $\left(C_{0}+C\right)$. The evaluator of spatial dependence (SD) analysis was made according to the following expression (GS+, 2004):

$S D=\left[C /\left(C+C_{0}\right)\right] .100$

wherein: SD is the evaluator of spatial dependence; $C$, the structural variance; and $C$ $+\mathrm{C}_{0}$, the level.

The proposed interpretation for the SD was the next: ESD $\leq 25 \%$ Indicated spatial variable weakly dependent; $25 \%<$ ESD $\leq 75 \%$ indicated spatial variable moderately dependent; and ESD > 75\% indicated spatial variable strongly dependent.

On the other hand, it is known that the crossed validation is a tool to assess alternative models of simple semivariograms and crossed, that respectively will make the kriging and the co-kriging. In its analysis, each point contained within the spatial domain is removed individually, and its estimated value as if it did not exist. In this way, can build a graph of the estimated values against the observed for all points. The correlation coefficient $(r)$ between both values reflects the setting efficiency, given by the technique of the sum of squares of the deviations, representing the linear regression equation in question. A perfect adjustment would have the regression coefficient equal to 1 and the line of the best adjustment would coincide with the perfect model, in other words, with the linear coefficient equal to zero and the slope equal to 1 (GS+, 2004). Thus, working on getting the ideal number of neighbors, were obtained, through interpolation, the kriging, and co-kriging maps, for spatial dependency and interdependence analysis between attributes. The geostatistical components determined were simple semivariogram, crossed semivariogram, crossed validation, kriging, and the co-kriging.

\section{RESULTS AND DISCUSSION}

The average value obtained for pasture height is considered adequate to evaluate fodder production dynamics, once this value is similar to the average values found by Pedreira (2006), who had observed average height $U$. brizantha pasture of $29.5 \mathrm{~cm}$ under rotational grazing. The average DMF $(8400 \mathrm{~kg}$ $\left.\mathrm{ha}^{-1}\right)$ was above the value suggested by Carvalho et al. (2004), of $2000 \mathrm{~kg} \mathrm{ha}^{-1}$ DM in order of not limit the consumption of animals (Table 1).

The average values of soil chemical attributes $\left(\mathrm{mg} \mathrm{dm}^{-3}\right)$ were classified according to Ribeiro Filho (1999) for the state of São 
Paulo as: low to $\mathrm{Cu}_{1}$ (1.43) and $\mathrm{Cu}_{2}$ (1.29); medium for $\mathrm{Zn}_{1}$ (2.18) and $\mathrm{Zn}_{2}$ (1.33), $\mathrm{Mn}_{1}$ (5.29) and $\mathrm{Mn}_{2}$ (4.24); and high for, $\mathrm{Fe}_{1}$ (120.6), $\mathrm{Fe}_{2}$ (87.06) and $\mathrm{B}_{1}(0.32)$ and $\mathrm{B}_{2}(0.30)$ (Table 1).

According to Magalhães et al. (2002), average values of $\mathrm{Zn}$ reinforce the idea that to be one of the most limiting micronutrients of the soil for the agricultural exploitation, in the study area would be a bit limiting. The high values of Fe are in agreement with Raij et al. (1996) by stating that iron deficiencies are not being observed in tropical soils, which suggests that its availability in Nova Odessa Region is adequate.

For $\mathrm{B}, \mathrm{Cu}, \mathrm{Fe}, \mathrm{Mn}$ and $\mathrm{Zn}$ the averaged values found by Marques Júnior et al. (2015) were: a) B (0.4 $\left.\mathrm{mg} \mathrm{dm}^{-3}\right)$, b) Cu (2.6 $\left.\mathrm{mg} \mathrm{dm}^{-3}\right)$, c) Fe $\left(49.6 \mathrm{mg} \mathrm{dm}^{-3}\right)$, d) $\mathrm{Mn}\left(13.6 \mathrm{mg} \mathrm{dm}^{-3}\right)$ and e) $\mathrm{Zn}\left(1.4 \mathrm{mg} \mathrm{dm}^{-3}\right)$, being these similar to the average values obtained in this study for $B, C u$, and $\mathrm{Zn}$. Although, for the Fe values obtained by the authors, are lower than those observed in this research.

Table 1. Initial descriptive analysis of the productive components of the fodder and of some soil micronutrient levels.

\begin{tabular}{|c|c|c|c|c|c|c|c|c|c|c|}
\hline Attribute ${ }^{(a)}$ & Average & Median & Minimum & Maximum & SD & CV (\%) & Kurtosis & Skewness & $\operatorname{Pr}<W$ & DF \\
\hline Hei $(\mathrm{cm})$ & 30.8 & 28.3 & 0.0 & 73.3 & 16.21 & 52.7 & 0.178 & 0.324 & 0.0001 & IN \\
\hline $\mathrm{DMF}\left(\mathrm{t} \mathrm{ha} \mathrm{C}^{-1}\right)$ & 8.47 & 8.5 & 0.0 & 19.7 & 4.37 & 51.7 & -0.018 & -0.135 & 0.0003 & IN \\
\hline $\operatorname{Cu} 1\left(\mathrm{mg} \mathrm{dm}^{-3}\right)$ & 1.43 & 1.40 & 0.1 & 2.8 & 0.44 & 30.38 & 0.580 & 0.53 & 0.0005 & IN \\
\hline $\mathrm{Cu} 2\left(\mathrm{mg} \mathrm{dm}^{-3}\right)$ & 1.29 & 1.20 & 0.5 & 2.6 & 0.38 & 29.8 & 0.70 & 0.68 & 0.0001 & IN \\
\hline Fe1 (mg dm $\left.{ }^{-3}\right)$ & 120.6 & 118.0 & 18.0 & 272.0 & 49.42 & 40.98 & 0.09 & 0.45 & 0.0286 & $\mathrm{TN}$ \\
\hline $\mathrm{Fe} 2\left(\mathrm{mg} \mathrm{dm}^{-3}\right)$ & 87.06 & 83.0 & 8.0 & 195.0 & 36.49 & 41.91 & -0.27 & 0.42 & 0.0091 & IN \\
\hline $\mathrm{Zn} 1\left(\mathrm{mg} \mathrm{dm} \mathrm{m}^{-3}\right)$ & 2.18 & 1.6 & 0.3 & 15.0 & 2.04 & 93.27 & 16.07 & 3.57 & 0.0001 & IN \\
\hline $\mathrm{Zn} 2\left(\mathrm{mg} \mathrm{dm}^{-3}\right)$ & 1.33 & 1.0 & 0.2 & 15.0 & 1.45 & 108.71 & 45.20 & 5.75 & 0.0001 & IN \\
\hline $\mathrm{Mn} 1$ (mg dm${ }^{-}$ & 5.29 & 5.0 & 1.3 & 11.5 & 2.01 & 38.06 & 0.03 & 0.55 & 0.0023 & IN \\
\hline $\mathrm{Mn} 2(\mathrm{mg} \mathrm{dm}-$ & 4.24 & 3.80 & 0.9 & 10.4 & 2.31 & 54.4 & 0.40 & 0.99 & 0.0001 & IN \\
\hline $\mathrm{B} 1\left(\mathrm{mg} \mathrm{dm} \mathrm{m}^{-3}\right)$ & 0.32 & 0.33 & 0.12 & 0.87 & 0.12 & 37.4 & 2.29 & 0.86 & 0.0001 & IN \\
\hline $\mathrm{B} 2\left(\mathrm{mg} \mathrm{dm}^{-3}\right)$ & 0.30 & 0.30 & 0.12 & 0.64 & 0.10 & 33.5 & 0.04 & 0.32 & 0.0145 & $\mathrm{TN}$ \\
\hline
\end{tabular}

(a) Hei = plant height, DMF = Dry mass of the fodder; Cu, Fe, Zn, Mn and B of 1 to 2, are respectively the amounts of copper, iron, zinc, manganese and boron, collected in soil layers of 0-0.10 and 0.10-0.20 m; (b) DF = distribution of frequency, and, TN and IN respectively of the type tending to normal and indeterminate.

Table 2. Simple linear correlation matrix between some productive components of fodder and some soil micronutrient.

\begin{tabular}{|c|c|c|c|c|c|c|c|c|c|c|c|}
\hline \multirow{2}{*}{ Attributes ${ }^{(a)}$} & \multicolumn{11}{|c|}{ Coefficient of Correlation (b) } \\
\hline & Hei & DMF & $\mathrm{Cu}_{1}$ & $\mathrm{Cu}_{2}$ & $\mathrm{Fe}_{1}$ & $\mathrm{Fe}_{2}$ & $\mathrm{Zn}_{1}$ & $Z n_{2}$ & $\mathrm{Mn}_{1}$ & $\mathrm{Mn}_{2}$ & $\mathrm{~B}_{1}$ \\
\hline DMF & $0.620 * *$ & - & - & - & - & - & - & - & - & - & - \\
\hline $\mathrm{Cu}_{1}$ & $0.220 * *$ & -0.001 & - & - & - & - & - & - & - & - & - \\
\hline $\mathrm{Cu}_{2}$ & $0.172 *$ & -0.018 & $0.811^{* *}$ & - & - & - & - & - & - & - & - \\
\hline $\mathrm{Fe}_{1}$ & $0.321 * *$ & $0.358 * *$ & 0.137 & 0.111 & - & - & - & - & - & - & - \\
\hline $\mathrm{Fe}_{2}$ & $0.186^{* *}$ & $0.226 * *$ & 0.016 & $0.208 * *$ & $0.778 * *$ & - & - & - & - & - & - \\
\hline $\mathrm{Zn}_{1}$ & 0.053 & 0.020 & $0.496 * *$ & $0.446 * *$ & -0.080 & -0.103 & - & - & - & - & - \\
\hline $\mathrm{Zn}_{2}$ & -0.009 & 0.005 & $0.433^{* *}$ & $0.438 * *$ & -0.124 & -0.031 & $0.846 * *$ & - & - & - & - \\
\hline $\mathrm{Mn}_{1}$ & $0.244^{* *}$ & $0.354^{* *}$ & 0.132 & $0.156^{*}$ & $0.458^{* *}$ & $0.393^{* *}$ & 0.023 & -0.040 & - & - & - \\
\hline $\mathrm{Mn}_{2}$ & $0.181^{*}$ & $0.267^{* *}$ & -0.010 & $0.215^{* *}$ & $0.264 * *$ & $0.426 * *$ & -0.059 & 0.018 & $0.748^{* *}$ & - & - \\
\hline $\mathrm{B}^{1}$ & $0.190 * *$ & $0.186^{* *}$ & -0.016 & -0.042 & $0.250 * *$ & $0.160 *$ & -0.028 & -0.064 & $0.200 * *$ & 0.126 & - \\
\hline$B^{2}$ & 0.082 & 0.058 & 0.056 & 0.076 & $0.228 * *$ & $0.180^{*}$ & -0.092 & -0.104 & $0.227^{* *}$ & $0.167 *$ & $0.206 * *$ \\
\hline
\end{tabular}

(a): Hei = height of the fodder, DMF = dry mass of the fodder; $\mathrm{Cu}, \mathrm{Fe}, \mathrm{Zn}, \mathrm{Mn}$ and $\mathrm{B}$ of 1 to 2 , are respectively the levels of copper, iron, zinc, manganese and boron, collected in soil layers $0-0.10$ and $0.10-0.20 \mathrm{~m}$; (b): ${ }^{*}$ significant at $5 \%$ of probability, ${ }^{* *}$ significant at $1 \%$ of probability. 
The heterogeneity of micronutrient levels can be justified by the $\mathrm{pH}$ variation of the area that was around 5.3 to 6.0. When the soil has a $\mathrm{pH}$ in this range decrease the availability of these micronutrients in the soil, and by treating of a busy area with pasture under beef cattle, there are other factors which may have contributed to the heterogeneity of the attributes such as agricultural management, stool deposition of animals and fertilizer application of previous experiments (Vieira, 2014). According to Warrick \& Nielsen (1980), studying the variability of several soil attributes, they have found that, for some, the expressed variability by the coefficient of variation was lower than $10 \%$, while, for others, has overcome $1,000 \%$ so classified the variability in three levels: Low (CV $\leq 12 \%)$, medium ( $12 \%<\mathrm{CV} \leq 52 \%)$ and high (CV > 52 $\%)$.

Therefore, DMF, $\mathrm{Cu}_{1}, \mathrm{Cu}_{2}, \mathrm{Fe}_{1}, \mathrm{Fe}_{2}, \mathrm{Mn}_{1}, \mathrm{~B}_{1}$ and $\mathrm{B}_{2}$ attributes, presented an average variability with coefficient of variation of 51.7 \%, $30.38 \%, 29.8 \%, 40.98 \%, 41.91 \%, 38.06$ $\%$, $37.4 \%, 33.5 \%$, respectively. Such results were similar to those of Machado et al. (2007) that studying a Red Latosol A moderated clayey texture under conventional tillage, in uniform rectangular grid with 121 sampling points, in a depth of 0-0.2 $\mathrm{m}$, found an average variability for $\mathrm{B}, \mathrm{Cu}, \mathrm{Fe}$ and $\mathrm{Mn}$ with coefficients of variation of $31.11 \%, 30.17 \%$, $23.91 \%$ and $34.83 \%$, respectively.

For Hei, $Z n_{1}, Z n_{2}$, and $M n_{2}$ presented high variability with a coefficient of variation of $52.7 \%, 93.27 \%, 108.71 \%$ and $54.4 \%$. These data were conflicting to the one checked by Machado et al. (2007), whose found low variability to $\mathrm{Zn}$ with coefficient of variation of $31.93 \%$ in a Red Latosol with a very clayey texture, under conventional tillage, and attributed this effect to the great variation of the nutrient levels in the sampled area.

The skewness coefficient was most positive and ranged from $0.320\left(B_{2}\right)$ to $3.57\left(Z n_{1}\right)$, and only the DMF presented negative skewness (0.135). The anthropic soil use over time resulted in an increase in the heterogeneity of the chemical attributes due to the interaction process of its formation, soil management and culture, as described by Cavalcante et al. (2007).

According to Carvalho et al. (2002), this variability is mainly verified in the surface layers of the soil. As this is an area taken up by pasture with beef cattle, there are other sources of variability in the soil due to the agricultural management, as non-uniform deposition of animal waste and fertilizer application. Yet in the study area, the data variability of the soil chemical attributes can also be associated with the effect of research experiments conducted in small parcels, with dosages of fertilizers and managements.

The skewness coefficient is used to characterize how and how much do the frequency distribution moves away from the skewness: if Cs $>0$, It has a skewness distribution to the right; if $\mathrm{Cs}<0$, the skewness distribution is to the left; and if $\mathrm{Cs}=$ 0 , the distribution is symmetrical (Guimarães, 2004). Negative skewness values were only observed for DMF, indicating skewness distribution to the left, while the other attributes ( $\mathrm{Cu}, \mathrm{Fe}, \mathrm{Zn}, \mathrm{Mn}$, and $\mathrm{B}$ ) presented positive values of skewness, indicating skewness distribution to the right.

Regarding the $\mathrm{Fe}_{1}$ and $\mathrm{B}_{2}$ attributes to the presented frequency distribution was as it was tending to normal (Table 1). The frequency distribution of $\mathrm{Hei}, \mathrm{DMF}, \mathrm{Cu}_{1}, \mathrm{Cu}_{2}$, $F e_{2}, Z n_{1}, Z n_{2}, M n_{1}, M n_{2}$ and $B_{1}$ attributes was 
undetermined. These results corroborate with the Chaves and Farias (2009), which evaluating a Dystrophic Gray Argisol under sugarcane cultivation, in a mesh with 65 sampling points, at a depth of 0 to $0.3 \mathrm{~m}$, presented in its studies of indeterminate frequency distribution for $\mathrm{Mn}, \mathrm{Fe}$, and $\mathrm{Zn}$ and for the $\mathrm{Cu}$ level there was a frequency distribution of the normal type.

According to Cambardella et al. (1994), the value of the different median average is an indicative that outliers in the distribution, in other words, dominate the measures of central tendency in this study, the average of $\mathrm{Cu}_{1}, \mathrm{Cu}_{2}, \mathrm{Zn}_{1}, \mathrm{Mn}_{1}$, and $\mathrm{Mn}_{2}$ cannot be taken as good estimate of the central tendency of population values.

In Table 2 has a simple linear correlation matrix between the productive components of the fodder (Hei and DMF) and the levels of some soil micronutrients ( $\mathrm{Cu}, \mathrm{Fe}, \mathrm{Zn}, \mathrm{Mn}$ and $B)$. The correlations between DMF, Hei and soil micronutrient levels were significant for the pairs: 1) Hei $x$ DMF $\left(r=0.620^{* *}\right)$, 2) Hei $x$ $\left.\left.\mathrm{Cu}_{1}\left(r=0.220^{* *}\right), 3\right) \mathrm{Hei} \times \mathrm{Cu}_{2}\left(r=0.172^{*}\right), 4\right)$ Hei $x \mathrm{Fe}_{1}\left(r=0.321^{* *}\right)$ 5) Hei $\times \mathrm{Fe}_{2}(r=$ $\left.0.186^{* *}\right)$, 6) Hei $x \mathrm{Mn}_{1}\left(r=0.244^{* *}\right)$, 7) Hei $x$ $\left.\mathrm{Mn}_{2}\left(r=0.181^{*}\right), 8\right)$ Hei $\times \mathrm{B}_{1}\left(r=0.190^{* *}\right)$.

The correlation between Hei $\times$ DMF was positive due to its high productivity per hectare, which was influenced by several factors occurred in the area. The heterogeneity of cultivation of the pickets favored to its high productivity because the haystack residue from previous cultures has kept the soil moisture and the preservation of the nutrient levels.

According to Dantas (1991), the correlation between Hei $\times \mathrm{B}$, Hei $\times \mathrm{Cu}$, may be related to the nutrient cycling of soil subsurface layers for the surface layers through decomposition of plant remains, which can regulate the levels of boron and copper available for plants.

The correlation between $\mathrm{Hei} \times \mathrm{Fe}_{1}$ may be associated with the pre-existing level of $\mathrm{Fe}$ oxides in the Latosols. According to Malavolta (2006) Iron is an important enzymes constituent or activator and also has a structural function and participates in important processes. Among them are the photosynthesis, respiration, biological fixation of nitrogen, nitrogen and sulfur assimilation lignin and suberin synthesis and auxin metabolism, influencing the plant growth.

According to Werner et al. (1996), the lower $\mathrm{Mn}$ levels harm its physiological role and induce the characteristic symptoms such as lower tillering, thinner tillers, internode elongation of plant and reticulated chlorosis in the younger leaves, which may progress to necrosis. The low correlation between Hei $x$ Mn shows that pasture growth was not much influenced by the manganese.

The correlations between DMF and some soil chemical attributes presented statistical significance for the pairs: 1) DMF $\times \mathrm{Fe}_{1}(r=$ $\left.0.358^{* *}\right)$, 2) DMF X Fe $\left.2\left(r=0.226^{* *}\right), 3\right)$ DMF $x$ $\left.\mathrm{Mn}_{1}\left(r=0.354^{* *}\right), 4\right) \mathrm{DMF} \times \mathrm{Mn}_{2}(r=$ $\left.0.267^{* *}\right)$, 5) DMF $x B_{1}\left(r=0.186^{* *}\right)$.

The correlation between DMF $x B$ had resembled with the verified by Haddad and Kaldor (1982), which have also found, for the culture of alfalfa that there were no very significant increases in dry matter production when correlated with boron.

It was not observed correlation of the height of fodder and FDM with $\mathrm{Zn}$, a fact that may be explained by the average levels obtained. According to Marques et al. (2004) the soils in Atlantic forest region present total levels of $\mathrm{Zn}$ equivalent to half the value of the 
global average, being this finding attributed to the long and intense process of occurred weathering. However, several studies show reduced productivity of the cultures because of the deficiency of micronutrients highlighting the zinc deficiency (Fageria \& Baligar, 1997).

Under the correlations of plant attributes versus soil, there was the significance of the regressions of DMF in according to the $\mathrm{Fe}_{1}$, $\mathrm{Mn}_{1}$ and $\mathrm{B}_{1}$ levels (Figures $1 \mathrm{a}, \mathrm{b}, \mathrm{c}$ ) being verified direct linear adjusts. Therefore, when the higher levels of Fe1 (272 $\left.\mathrm{mg} \mathrm{dm}^{-3}\right)$, Mn1 (11.5 $\left.\mathrm{mg} \mathrm{dm}^{-3}\right)$ and B1 $\left(0.87 \mathrm{mg} \mathrm{dm}^{-3}\right)$ in the layer of 0 to $0.1 \mathrm{~m}$, these will imply in maximum values estimated of DMF of $13.3 \mathrm{t}$ $\mathrm{ha}^{-1}, 12.5 \mathrm{t} \mathrm{ha}^{-1}$ and $12.04 \mathrm{t} \mathrm{ha}^{-1}$ respectively. Attesting the importance of micronutrients available for the production increase of the fodder, mainly in pasture area wherein the cultures remain is primary sources of O.M. for nutrient cycling, since well managed. In Table 3 and Figure 2, are presented the model's parameters for each semivariogram and the respective semivariograms. Thus, it was certified that $\mathrm{Mn} 1, \mathrm{Mn} 2, \mathrm{~B} 2$, presented nugget effect, and the other attributes presented spatial dependence. With regard to the performance of the semivariograms, their decreasing relation, analyzed by the greatness of the coefficient of spatial determination (r2), was the following: 1) Hei (0.988), 2) DMF (0.984), 3) Fe1 (0.964), 4) Cu1 (0.952), 5) Cu2
(0.926), 6) Fe2 (0.902), 7) B1 (0.719), 8) Zn2 (0.689) and 9) Zn1 (0.616).

Thus, in concerning to the first three (Hei, DMF, $\mathrm{Fe}_{1}$ ), which have high coefficients of spatial determination, was observed the following: to Hei, the value of $r^{2}$ (0.988) has indicated being such attribute with the best semivariographic adjust.

Regarding the models, the spherical and exponential had presented as the most common to soil and plant attributes (Trangmar et al., 1985). In relation to the DMF, the high dependence verified (ESD $=73$ $\%)$ and the spherical model is also in accordance with Bezerra (2008), that while studying the spatial variability productivity of season maize fodder according to the soil chemical attributes found spherical model in the semivariographic with high spatial dependence (ESD $=73.5 \%$ ).

For the $\mathrm{Fe}_{1}$, its value of $\mathrm{r}^{2}$ is 0.964 and ESD = $69 \%$, has indicated to be such attribute the third of best semivariographic adjust. Agreeing with that checked by Zanão Júnior et al. (2010), which when studying the spatial variability of chemical attributes at 0-0.1 and 0.1-0.2 m depths in an Oxisol under no-tillage system found spherical model semivariographic with a spatial dependence average $(\mathrm{ESD}=60.01 \%)$ 


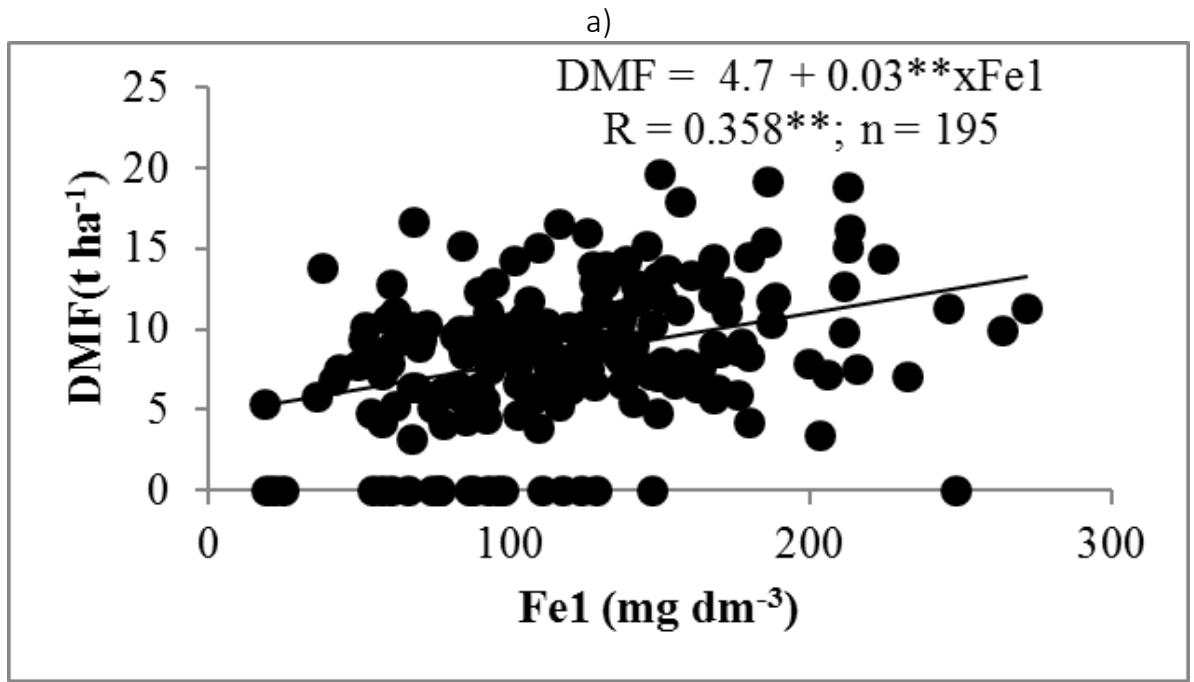

b)

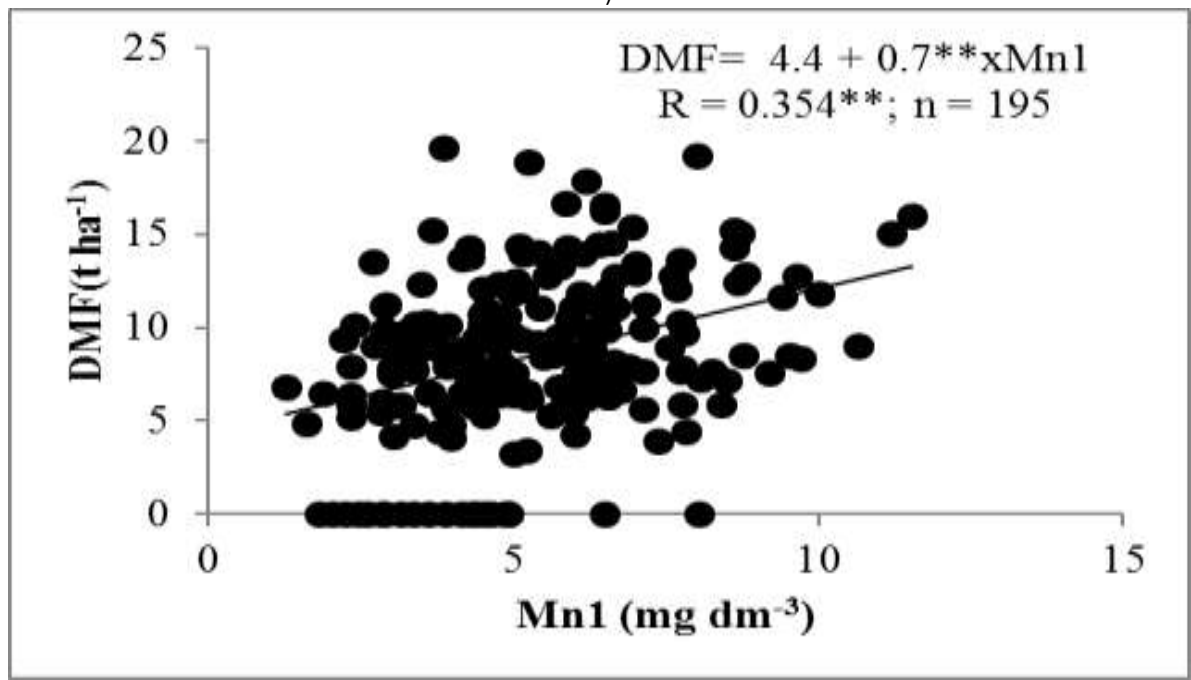

c)

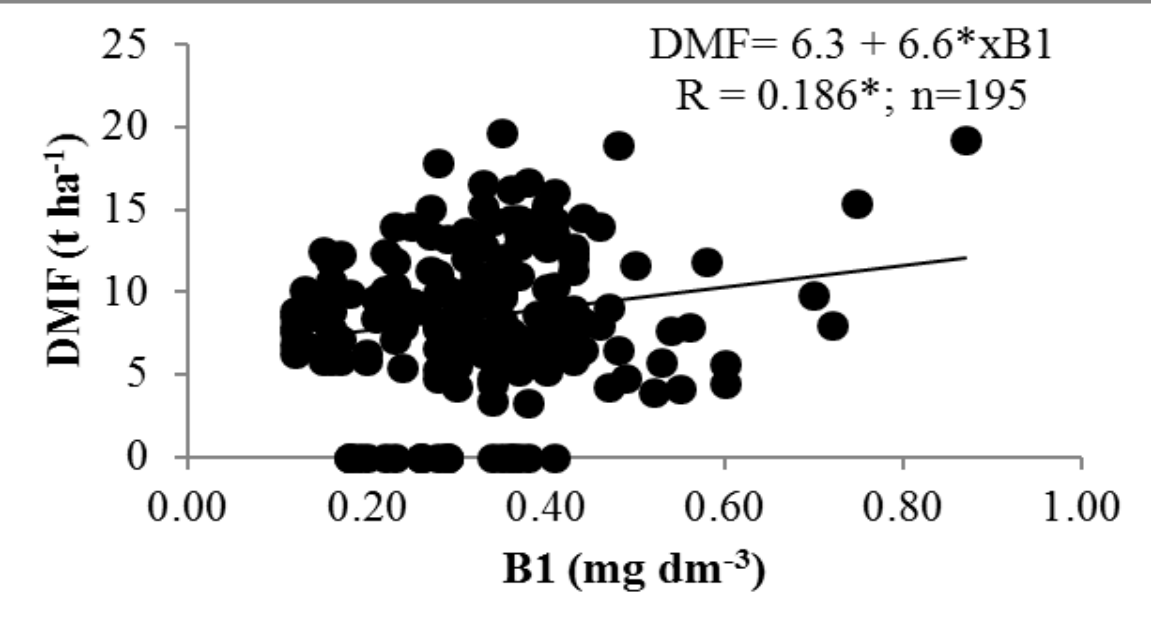

Figure 1. Dry mass of the fodder regression equations and of some attributes of soil micronutrients. 
Table 3. Parameters of the simple semivariograms adjusted for some productive components of the fodder and some soil micronutrient.

\begin{tabular}{|c|c|c|c|c|c|c|c|c|}
\hline \multirow[t]{2}{*}{ Attribute (a) } & \multirow[t]{2}{*}{ Model (b) } & \multirow{2}{*}{$\begin{array}{c}\text { Nugget } \\
\text { effect } \\
\left(C_{0}\right)\end{array}$} & \multirow{2}{*}{$\begin{array}{l}\text { Level } \\
\left(C_{0}+C\right)\end{array}$} & \multirow{2}{*}{$\begin{array}{l}\text { Range } \\
\left(R_{0}-m\right)\end{array}$} & \multirow[t]{2}{*}{$r^{2}$} & \multirow[t]{2}{*}{$S R S^{\text {(c) }}$} & \multicolumn{2}{|c|}{$\begin{array}{c}\text { Evaluator of spatial } \\
\text { dependence }\end{array}$} \\
\hline & & & & & & & $\mathrm{ESD}^{\text {(d) }}$ & Class \\
\hline \multicolumn{9}{|c|}{$v(h)$ simple of the fodder attributes } \\
\hline Hei $(\mathrm{cm})$ & $\operatorname{sph}(62)$ & $9.120,10$ & $3.050,10^{2}$ & 192.0 & 0.988 & $4.620,10^{2}$ & 70.0 & High \\
\hline $\mathrm{DMF}\left(\mathrm{t} \mathrm{ha}^{-1}\right)$ & sph (62) & 5.850 & $2.188,10$ & 285.6 & 0.984 & 5.11 & 73.0 & High \\
\hline \multicolumn{9}{|c|}{$\gamma(h)$ simple of the soil chemical attributes } \\
\hline $\mathrm{Cu}_{1}\left(\mathrm{mg} \mathrm{dm} \mathrm{dm}^{-3}\right)$ & sph (62) & $8.400,10^{-3}$ & $1.978,10^{-1}$ & 141.0 & 0.952 & $1.293,10^{-3}$ & 95.0 & Very high \\
\hline $\mathrm{Cu}_{2}\left(\mathrm{mg} \mathrm{dm}^{-3}\right)$ & $\operatorname{sph}(62)$ & $3.530,10^{-2}$ & $1.516,10^{-1}$ & 145.0 & 0.926 & $8.127,10^{-4}$ & 76.7 & High \\
\hline $\mathrm{Fe}_{1}\left(\mathrm{mg} \mathrm{dm} \mathrm{dm}^{-3}\right)$ & $\operatorname{sph}(62)$ & $7.300,10^{2}$ & $2.425,10^{3}$ & 113.2 & 0.964 & $5.817,10^{4}$ & 69.0 & High \\
\hline $\mathrm{Fe}_{2}\left(\mathrm{mg} \mathrm{dm}{ }^{-3}\right)$ & $\exp (62)$ & $3.920,10^{2}$ & $1.574,10^{3}$ & 379.5 & 0.902 & $7.510,10^{-1}$ & 64.1 & High \\
\hline $\mathrm{Zn}_{1}\left(\mathrm{mg} \mathrm{dm}{ }^{-3}\right)$ & sph (62) & 1.542 & 4.396 & 135.5 & 0.616 & 3.420 & 65.0 & High \\
\hline $\mathrm{Zn}_{2}\left(\mathrm{mg} \mathrm{dm}^{-3}\right)$ & sph (52) & $1.790,10^{-1}$ & 2.229 & 126.9 & 0.689 & 1.180 & 92.0 & Very high \\
\hline $\mathrm{Mn}_{1}\left(\mathrm{mg} \mathrm{dm}^{-3}\right)$ & ne & 4.502 & 4.502 & - & - & - & - & - \\
\hline $\mathrm{Mn}_{2}\left(\mathrm{mg} \mathrm{dm} \mathrm{m}^{-3}\right)$ & ne & 8.143 & 8.143 & - & - & - & - & - \\
\hline $\mathrm{B}_{1}\left(\mathrm{mg} \mathrm{dm}^{-3}\right)$ & gau (62) & $1.000,10^{-5}$ & $1.321,10^{-2}$ & 50.0 & 0.719 & $1.085,10^{-5}$ & 99.0 & Very high \\
\hline $\mathrm{B}_{2}\left(\mathrm{mg} \mathrm{dm}^{-3}\right)$ & ne & $9.205,10^{-3}$ & $9.205,10^{-3}$ & - & - & - & - & - \\
\hline
\end{tabular}

(a) Hei = Fodder heigh, DMF = dry mass of fodder; $\mathrm{Cu}, \mathrm{Fe}, \mathrm{Zn}, \mathrm{Mn}$ and $\mathrm{B}$ of 1 to 2 , are respectively the levels of copper, iron, zinc, manganese and boron, collected in soil layers of 0-0.10 and 0.10-0.20m; (b) exp = exponential, gau = gaussian, $\mathrm{sph}=$ spherical e ne = Nugget effect; succeed model by number in parentheses, means the number of pairs in the first lag; (c) $S R Q=$ sum of residue squares; (d) ESD = Evaluator of spatial dependence.

Marques Júnior et al. (2015), when studied the spatial variability of the micronutrients $B$, $\mathrm{Fe}, \mathrm{Cu}, \mathrm{Mn}$ and $\mathrm{Zn}$ in soils of the state of São Paulo at a depth of 0-0.2 m, they found a spherical model in the semivariogram for all analyzed attributes.

In table 3 , the decreasing relation of the ranges was the following: 1) $\mathrm{Fe}_{2}(379.5 \mathrm{~m}), 2$ ) DMF (285.6 m), 3) Hei (192.0 m), 4) $\mathrm{Cu}_{2}$ (145.0 m), 5) Cu$(141.0 \mathrm{~m}), 6) \mathrm{Zn}_{1}(135.5 \mathrm{~m})$, 7) $\left.Z n_{2}(126.9 \mathrm{~m}), 8\right) \mathrm{Fe}_{1}(113.2 \mathrm{~m})$ and 9) $B_{1}$ (50.09 m). Therefore, under the conditions of this research, as well as, seeking to support future searches, in which the same attributes are involved, the values of the ranges to be used in geostatistical packages, that will feed the computational packages employed in precision agriculture, in general, would not be lower than $50 \mathrm{~m}$.

In Figure 3 are presented the kriging maps of Hei and DMF, as well as the levels of some micronutrients of an abrupt Dystrophic RedYellow Argisol from Nova Odessa - SP. In Figure $3 a$, it is observed the kriging map of plant height (Hei), where is most present in the areas $R 1, R 2, R 4, T$ and $C$ being in the area R1, R2 and R4 there was Urochloa decumbers and several fodders, while in the $T$ area there was maize and in area $C$, sugarcane. These high values of (Hei) are directly related to the type of occupation of the area. 
a)

Ait $(\mathrm{cm})$

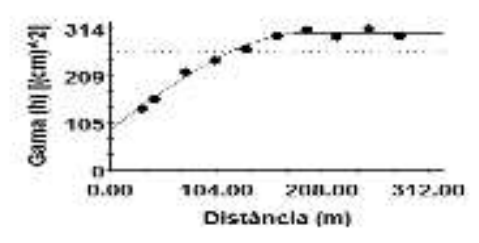

c)

Cu1 (mg/am^3)

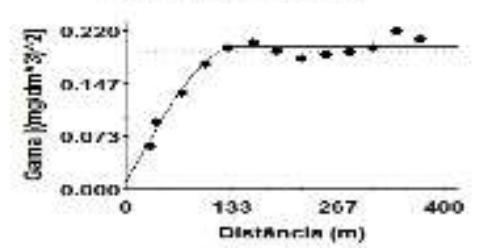

e)

Fe1 (mg/dm^3)

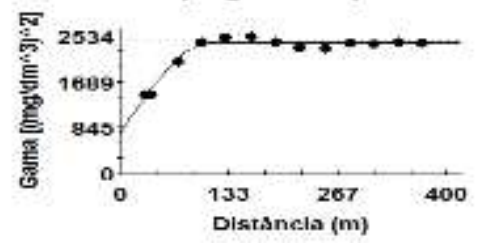

g)

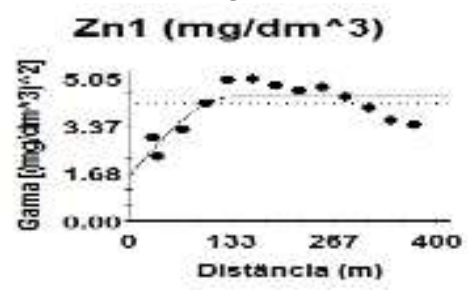

b)

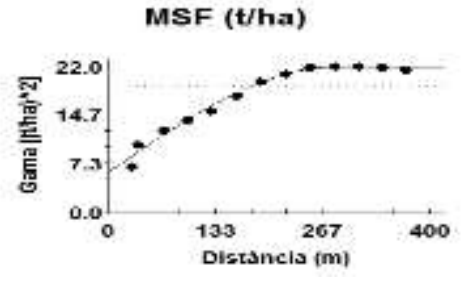

d)

cu2 (mo/dm^3)

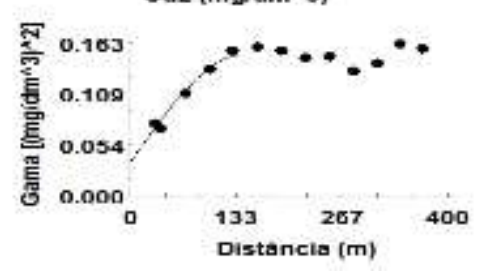

f)

Fe2 (mg/dm^3)

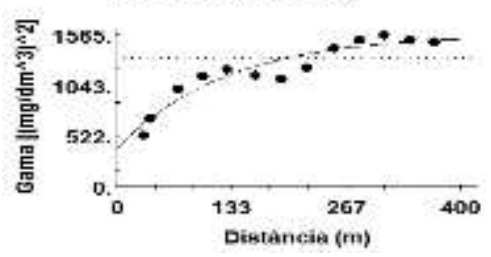

h)

$\mathrm{Zn} 2$ (mg/dm^3)

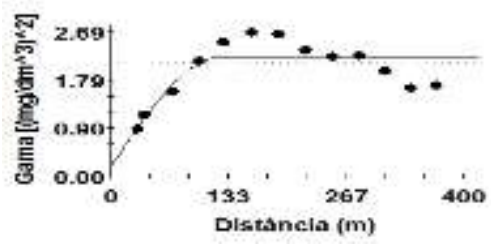

i)

B1 (mg/dm^3)

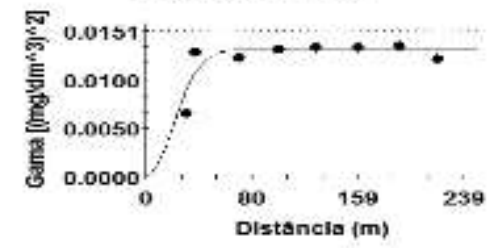

Figure 2. simple semivariograms of productive components of the forage and soil micronutrient contents. 
a)
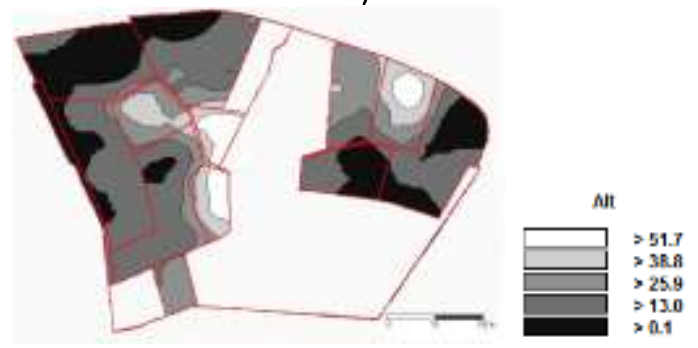

c)

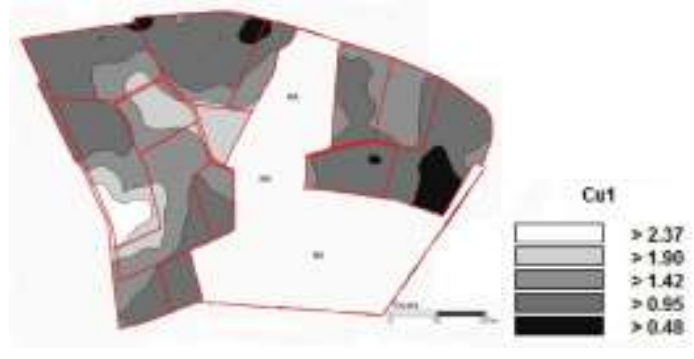

e)

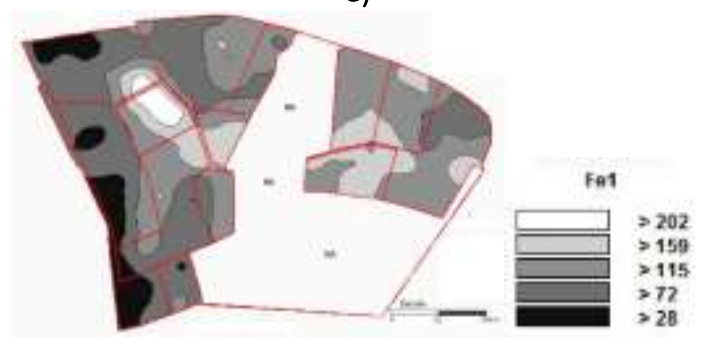

g)

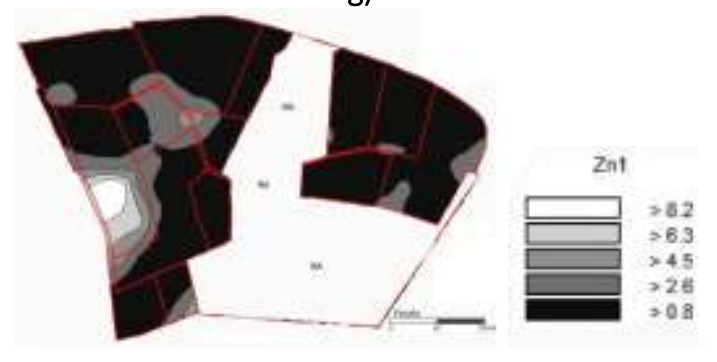

b)

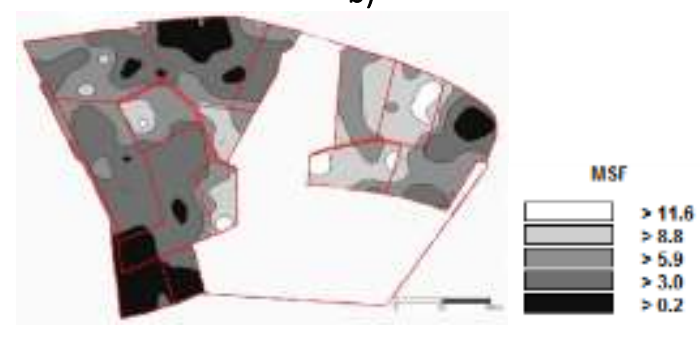

d)

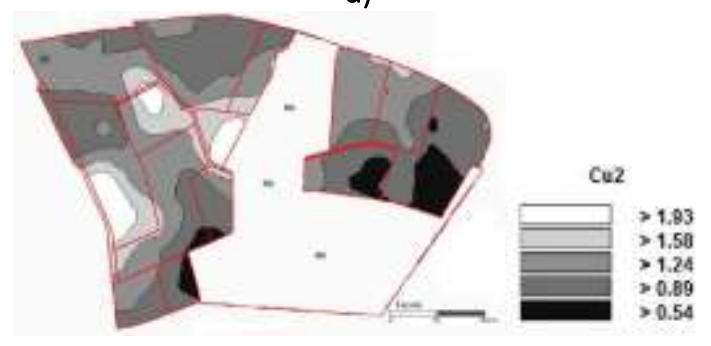

f)

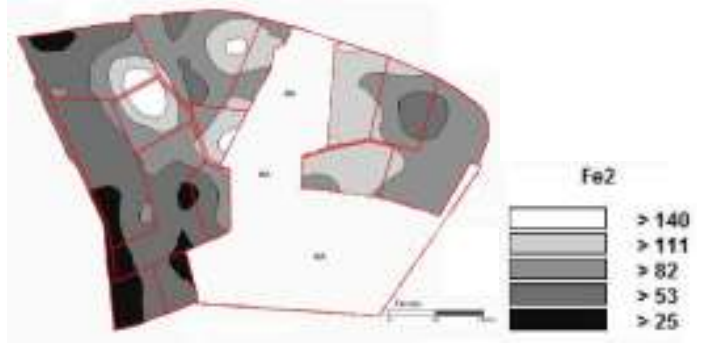

h)

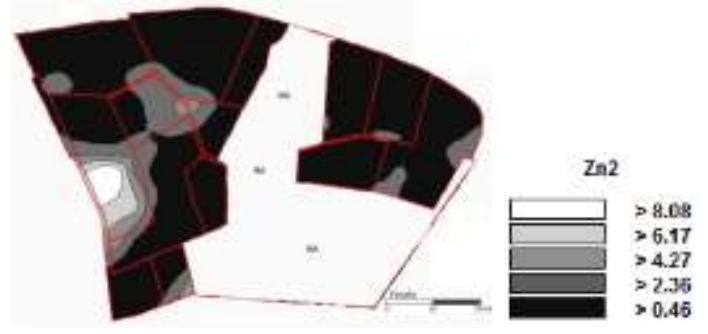

i)

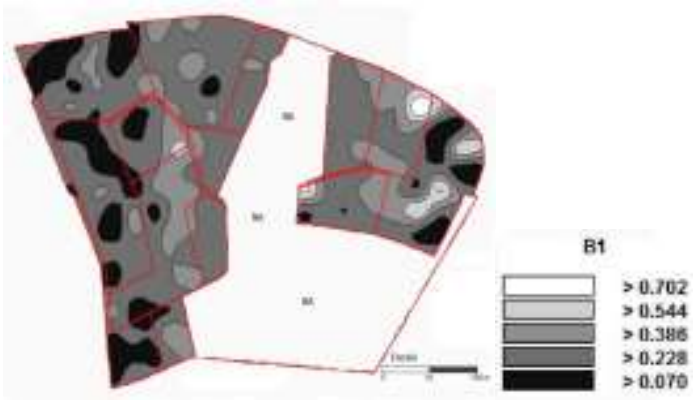

Figure 3. kriging maps of productive components of the fodder (Hei, in cm; DMF in tha-1) and soil micronutrient levels (mg dm-3). 
Evaluating the dry matter of fodder (DMF) was verified a well-defined range in the R1 area, being occupied by Urochloa decumbens and several fodders. For the $\mathrm{Cu}_{1}$ levels, in Figure $3 c$ was found a well-defined range in the southern region of the P6 area, being observed a high direct similarity to the kriging map of $\mathrm{Cu}_{2}$ (Figure $3 \mathrm{~d}$ ).

Co-kriging analysis attempts were carried out among all the attributes, although there were no spatial adjustments, presenting only the nugget effect.

\section{CONCLUSIONS}

The fodder dry mass productivity can be explained by mathematical models of high significance, according to the soil boron, iron and manganese levels for the depth of $0-0.10$ $\mathrm{m}$. The higher ranges of spatial dependence were observed for the fodder dry mass attributes with a range of $285.6 \mathrm{~m}$ and iron level in the soil with a range of $379.5 \mathrm{~m}$, in the depth $0.10-0.20 \mathrm{~m}$. The use of the average of the micronutrient levels in the soil may result in errors in the recommendation of fertilization, with an excess of micronutrients points and others with the deficit, by virtue of its high spatial variability. Although it was not possible to adjust the co-kriging maps of Hei $x$ DMF, was possible through kriging maps to observe a high spatial similarity between Hei and DMF.

\section{REFERENCES}

Bezerra, C.R.F. 2008. Variabilidade espacial da produtividade de forragem de milho safrinha em função de atributos químicos do solo. 2008. $71 \mathrm{f}$.
Dissertação (Mestrado em Agronomia), Faculdade de Engenharia/Unesp, Campus de Ilha Solteira, 2008.

Cambardella, C.A.; Moorman, T.B.; Novak, J.M.; Parkin, T.B.; Karlen, D.L.; Turco, R.F.; Konopka, A.E. 1994 Field-scale variability of soil properties. in Central lowa soils. Soil Science Society of America Journal, Madson, v.58, n.5, p.1501-1511.

Carvalho, M.P.; Soratto, R.P., Freddi, O.S. 2002. Variabilidade espacial de atributos físicos em um Latossolo Vermelho Distrófico sob preparo convencional em Selvíria, estado de Mato Grosso do Sul. Acta Scientiarum Agronomy, Maringá, v. 24, n.5, p.1353-1361.

Carvalho, P.C.F.; Canto, M.W.; Moraes, A. 2004. Fontes de perdas de forragem sob pastejo: In: Pereira, O.G.; Obeid, J.A.; Fonseca, D.M.; Nascimento JR., D. (Eds.). Manejo estratégico da pastagem. 1.ed. Viçosa, MG: Suprema Gráfica e Editora, 2004. v.1, p.387-418.

Cavalcante, E.G.S.; Alves, M.C.; Souza, Z.M. Pereira, G.T. 2007. Variabilidade espacial de atributos químicos do solo sob diferentes usos e manejos. Revista Brasileira de Ciência do Solo, Viçosa, v.31, n.6, p.1329-1339.

CEPAGRI. 2013. Centro de Pesquisas Meteorológicas E Climáticas Aplicadas à Agricultura. Clima das cidades do Estado de São Paulo. 2013. Disponível em: <http://www.cpa.unicamp.br/outrasinformacoes/clima_muni_379.html>. Acesso em: 09. Jan. 2014.

Dias-Filho, M.B. 2014. Diagnóstico das pastagens no Brasil . Belém, PA: Embrapa Amazônia Oriental.

EMBRAPA. 2013. Empresa Brasileira De Pesquisa Agropecuária. Centro Nacional de Pesquisa de Solos. Sistema Brasileiro de Classificação de Solos. 3. ed. Rio de Janeiro, 2013. 353p.

Fageria, N.K.; Baligar, V.C. 1997. Response of common bean, upland rice, corn, wheat, and soybean to soil fertility of an Oxisol. Journal of Plant Nutrition, New York, v.20, n. 10 p.12791289. 
GS+. 2004. Geostatistics for environmental sciences. 7. ed. Michigan, Plainwell: Gamma Desing Software, 2004. 159p.

Guimarães, E.C. 2004.Geoestatística básica e aplicada. Uberlândia: UFU - Núcleo de Estudos Estatísticos e Biomédicos, 2004. 77 p.

Haddad, K.S.; Kaldor, C.J. 1982. Effect of parent material, natural available soil boron, and applied boron and lime on the growth and chemical composition of lucerne on some acidic soils of the central Tablelands of New South Wales. Journal of Experimental Agriculture and Animal Husbandry, Australian, v. 22, n. 117, p. 317-323.

Macedo, J.R.; Otonni Filho, T.B.; Meneguelli, N.A. 1995. Variabilidade de características físicas, químicas e físico-hídricas em solo Podzólico Vermelho-Amarelo de Seropédica, Pesquisa Agropecuária Brasileira, Brasília, v.33, n. 12, p.2043-2053.

Machado, L.O.; Lana, A.M.Q.; Lana, R.M.Q.; Guimarães, E.C.; Ferreira, C.V. 2007. Variabilidade espacial de atributos químicos do solo em áreas sob sistema plantio convencional. Revista Brasileira de Ciência do Solo, Viçosa, v. 31, n.3, p. 591-599.

Magalhães, R.T.; Oliveira, I.P.; Kliemann, H.J. 2002. Relações da produção de massa seca e as quantidades de nutrientes exportados por Brachiaria brizantha em solos sob o manejo pelo sistema "barreirão". Pesquisa Agropecuária Tropical, Goiânia, v.32, n.1, p.13-20.

Malavolta, E. 2006. Elementos da nutrição mineral de plantas. São Paulo: Agronômica Ceres, 2006. $638 \mathrm{p}$.

Marques Júnior, J.; Alleoni, L.R.F.; Teixeira, D.B.; Siqueira, D.S.; Pereira, G.T. 2015. Sampling planning of micronutrients and aluminium of the soils of São Paulo, Brazil. Geoderma Regional, Amsterdam, v. 4, n.1, p.91-99.

Marques Júnior, J.; Schulze, D.G.; Curi, N.; Mertzman, S.A. 2004. Trace element geochemistry in Brazilian Cerrado soils. Geoderma Regional, Amsterdam, v.121, n.2, p.31-43.

Moreira, J.A.A.; Oliveira, I.P. 2005. Atributos químicos e físicos de um latossolo vermelho distrófico sob pastagens recuperada e degradada. Pesquisa Agropecuária Tropical, Goiânia, v. 35, n.3, p. 155-161.

Raij, B. van. et al. Análise química para avaliação da fertilidade de solos tropicais. Campinas: Instituto Agronômico, 2001. 285p.

van RAIJ, B.; Cantarella, H.; Quaggio, J.A.; Furlani, A.M.C. 1996. Recomendações de adubação e calagem para o Estado de São Paulo. Instituto Agronômico e Fundação IAC: Campinas, 1996. $255 p$.

Ribeiro-Filho, M.R.; Curi, N.; Siqueira, J.O.; Motta, P.E.F. 1999. Metais pesados em solos de área de rejeitos de indústria de processamento de zinco. Revista Brasileira de Ciência do Solo, Viçosa, v. 23, n. 2, p. 453-464.

Schlotzhaver, S.D.; Littell, R.C. 1997. SAS System for elementary statistical analysis. 2.ed. Cary, 1997. 905p.

Silva, V.R.; Reinert, D.J.; Reichert, J.M. 2000. Resistência mecânica do solo à penetração influenciada pelo tráfego de uma colhedora em dois sistemas de manejo do solo. Ciência Rural, Santa Maria, v.30, n.5, p.795-801.

Trangmar, B.B.; Yost, R.S.; Wade, M.K.; Uehara, G. 1985. Applications of geostatistics to spatial studies of soil properties. Advance Agronomy, San Diego, v. 38, n.1, p. 45-94.

Vieira, G.F.A. 2014. Variabilidade espacial de atributos químicos do solo sob pastagem em um sistema de produção de bovinos de corte. 2014. 152f. Dissertação (Mestrado em Produção Animal) - Agência Paulista de Tecnologia dos Agronegócios, Instituto de Zootecnia, Nova Odessa.

Warrick, A.W.; Nielsen, D.R. 1980. Spatial variability of soil physical properties in the field. In: Hillel, D., ed. Applications of soil physics. New York, Academic Press, 1980. cap. 13, p.319-344.

Werner, J.C.; Paulino, V.T.; Cantarella, H.; Andrade, N.O.; Quaggio, J.A. 1996. Forrageiras. In: Raij, B. van; Cantarella, H.; Quaggio, J. A.; Furlani, A. M. C. Recomendações de adubação e calagem para o Estado de São Paulo. Instituto Agronômico e Fundação IAC: Campinas, 1996.p.263-273. 
Zanão Júnior, L.A.; Lana, R.M.Q.; Guimarães, E.C.; Pereira, J.M.A. 2010. Variabilidade espacial de atributos químicos em diferentes profundidades em um latossolo em sistema de plantio direto. Revista Ceres, v. 57, n. 3, p. 429-438. 